\title{
The 4D Model of the country image: An integrative approach from the perspective of communication management
}

\author{
Alexander Buhmann \\ Department of Communication and Media Research (DCM), \\ University of Fribourg, Fribourg, Switzerland

\section{Diana Ingenhoff} \\ Department of Communication and Media Research (DCM), \\ University of Fribourg, Fribourg, Switzerland
}

\begin{abstract}
This conceptual article proposes a new integrative model of the country image by drawing on advances from the fields of business studies, social psychology, political science, and communication science. To interrelate different approaches, a communication management perspective is applied, providing a basic terminological framework systemizing the central constructs of country image, country reputation, country brand, and country identity. On this basis the authors develop the '4D Model' of the country image by integrating well-established concepts from national identity theory, attitude theory, and reputation management. The new model is suited for application in comparative analyses of country images both on the level of different groups (such as a country's domestic and foreign publics) as well as different societal levels (such as individual attitudes on the one hand and mass-mediated prestige information on the other).
\end{abstract}

\section{Keywords}

Communication management, construct specification, country image dimensions, country of origin, international public relations, international relations, nation branding, public diplomacy

\section{Corresponding author:}

Diana Ingenhoff, Department of Communication and Media Research (DCM), University of Fribourg, Bd de Pérolles 90, 1700 Fribourg, Switzerland.

Email: diana.ingenhoff@unifr.ch 


\section{Introduction}

In times of globalization and mediatization, the image a country projects is becoming more important: as a recent historical trend the modern establishment of external observers of the state system - such as international organizations and media-has enforced new forms of competition between countries, shifting the focus onto 'soft goods' (Werron, 2014) such as image and reputation. Increasingly, countries are publicly rated and compared according to their economic development, political stability, the effectiveness and morality of their national and international policies, or the attractiveness of their culture. Research shows that the country image, as 'the cognitive representation that a person holds about a given country' (Kunczik, 2003, p. 412), has a wide range of effects: Country images critically influence foreign direct investment (Kotler and Gertner, 2002; Kunczik, 2002; Wee et al., 1993), the prosperity of national tourist industries (Chon, 1990; Gertner, 2010; Tapachi and Waryszak, 2000; Walmsley and Young, 1998), the attractiveness of domestic labor markets (Papadopoulos, 2004), and educational systems (Gertner, 2010; Srikatanyoo and Gnoth, 2002), as well as the stability of international relations and the degree of a country's political influence in the international system (Gilboa, 2008; Kunczik, 1997; Leonard et al., 2002; Sun, 2008; van Ham, 2008). Furthermore, country images have a major effect on the success of exports (Dichter, 1962; Papadopoulos and Heslop, 1993) because they influence the way people evaluate the quality of products and services (Han and Terpstra, 1988; Jaffe and Nebenzahl, 2001; Papadopoulos and Heslop, 1993) and, by implication, affect peoples' willingness to pay (Nebenzahl and Jaffe, 1996).

The growing importance of country images has raised the need to analyze and compare these constructs and their effects both in research and practice.

Political leaders are increasingly concerned about their country's esteem abroad (Kunczik, 2003; Price, 2003; Werron, 2014) and practices of communication management are widely applied on the level of the nation-state system (Dinnie, 2008; Kunczik, 1997; Snow and Taylor, 2009; van Dyke and Vercic, 2009). One such example is Switzerland, which on the basis of a 'Federal Act on the Promotion of Switzerland's image abroad' launched a separate unit in its Federal Department of Foreign Affairs that 'supports the protection of Switzerland's interests by using various public relations tools' with a yearly budget of over $9 \mathrm{~m}$. USD (FDFA, 2014).

In research, various facets of the phenomenon have been studied in the different fields of business studies (Dinnie, 2008; Roth and Diamantopoulos, 2009), social psychology (Brown, 2011; Cuddy et al., 2007), political science (Leonard et al., 2002; Wang, 2006), and communication science (Golan and Wanta, 2003; Kunczik, 1997). But sound conceptual models and appropriate measurement instruments to analyze and compare the constitution and effects of country images in different groups and contexts are rare. Most existing models lack theoretical foundations, cannot be applied to different countries or the comparative analysis of country images in different groups, often fail in comprehensively capturing all relevant dimensions, and refrain from clarifying the internal structure of the 
construct (Magnusson and Westjohn, 2011; Papadopoulos, 2004; Roth and Diamantopoulos, 2009). Furthermore, we see that Papadopoulos' (2004) statement regarding a strict segregation of research on country images between the different disciplinary perspectives is still true and there remains 'great need for integrative studies that would merge the available knowledge across the various fields' (2004, p. 47). But these fields vary in their conceptual understanding of the construct, and the central concepts of country image, country reputation, country brand, and country identity are defined differently, making integrative efforts difficult. These challenges raise the question of how available knowledge from the different fields of research can be structured and consolidated in order to produce an integrative model for analyzing country images.

In the following, three steps are taken to deal with this question: First, advances in the aforementioned research fields are introduced in a comprehensive and synoptical literature review to show the central lines of research in studying country images, characterize their respective level of analysis, and outline the underlying conceptual understandings of the construct. Second, a communication management perspective is applied to systemize the concepts of country image, country reputation, country brand, and country identity in a single framework that helps to link the different research perspectives. Third, an integrative model of the country image is derived by combining concepts from national identity theory, attitude theory, and reputation management.

\section{Literature review}

A first set of studies addressing the perception of countries can be found in the 1930s and 1940s (Child and Doob, 1943; Katz and Braly, 1933; Klingberg, 1941; Kusunoti, 1936). Since then, the fact that country images are both the cause and effect of social as well as psychological processes, together with the multitude of their possible economic, cultural, and political effects, has led to various studies across a range of scientific fields. This has led to a plethora of definitions of the relevant concepts and divergent specifications of their dimensions. The substantial corpus of literature can be systemized by distinguishing between the four research perspectives of business studies, social psychology, political science, and communication science.

\section{The business studies perspective}

From the perspective of business studies, the phenomenon is researched with an interest in questions regarding consumption behavior. Different concepts have been developed in the subfield of marketing with a focus on nation brands as well as country-of-origin effects.

In country-of-origin research, the study of the constitution and effects of country images have a long history, starting with the works of Dichter (1962) and Schooler (1965) (see Peterson and Jolibert, 1995; Roth and Diamantopoulos, 
2009; Verlegh and Steenkamp, 1999 for an overview of the field). Most of the studies have since conceptualized the country image as an attitudinal construct, suggesting a plethora of different dimensions and variables (Roth and Diamantopoulos, 2009). An important factor in many of the studies is the evaluation of the state of a country's economy (e.g., Martin and Eroglu, 1993; Wang and Lamb, 1983) as well as of its political system (e.g., Allred et al., 1999). Heslop et al. (2004) also suggest the work training and competences of the people as an important factor. Another factor often referred to is the degree of technological advancement (e.g., Desborde, 1990; Kühn, 1993; Martin and Eroglu, 1993). Despite the substantial body of research in this field, the theoretical foundation and empirical testing of the dimensionality of the country image is still labeled unsatisfactory (Newburry, 2012). When looking at the basic components of the attitudinal construct, most studies have a strong emphasis on cognitive dimensions and fail to consistently operationalize country affects (Roth and Diamantopoulos, 2009). With a few exceptions (Brijs et al., 2011; Häubl, 1996; Heslop et al., 2004), researchers also largely refrain from clarifying the internal structure of the construct, raising the question of how different cognitive and affective image dimensions interrelate and affect each other. Also, if interested in the country image as a generic construct, most country-of-origin research has limited utility due to its focus on product-country images as a joined construct (Peterson and Jolibert, 1995; Verlegh and Steenkamp, 1999). When empirically analyzing country images, the fields' focus on consumer research has left a gap of understanding with regard to other important groups such as foreign investors, politicians, political publics, students, or skilled workers (Papadopoulos, 2004). This is also strongly reflected in respective measurement models, since many researchers (like Puaschunder et al., 2004; Reindl and Schweiger, 2006; Schweiger, 1988, 1992; Schweiger and Kurz, 1997) develop these inductively from specific groups of consumers at a specific point in time. This leads to dimensions, which depend entirely on the focus of one specific group, in turn limiting applicability to comparative approaches analyzing different countries' images in different groups.

The field of nation branding is grounded in research regarding the constitution, measurement, and management of brands (see Kaneva, 2011; Papadopoulos, 2004 for an overview of the field). The nation brand is commonly defined as 'the unique, multi-dimensional blend of elements that provide the nation with culturally grounded differentiation and relevance for all of its target audiences' (Dinnie, 2008, p. 15). This construct is applied both on the level of branding strategy (output) as well as the respective perceptions of the nation brand in the mind of the consumer (outcome); in outcome analyses it is often specified in terms of general associations with a country (Brown et al., 2010; Puaschunder et al., 2004; Reindl and Schweiger, 2006). So far, works on nation branding are strongly influenced by practitioners (Anholt, 2006; Gilmore, 2002; Olins, 2002), have a rather specialized focus on the target group of tourists (Morgan et al., 2010; Tapachi and Waryszak, 2000), and are often qualitative, while theory-driven concepts and quantitative approaches are rare (Gertner, 2011). A central gap is the 
development of concepts and measures to evaluate the success of nation branding strategies (Papadopoulos, 2004), i.e., instruments to track the development and change of nation brands (Loo and Davies, 2006, p. 208).

\section{The social psychology perspective}

From the perspective of social psychology country images are analyzed regarding individual cognition, emotion, and behavior. The field has developed concepts of country image and country self-image (i.e., country identity) in the two subfields of intergroup relations and collective identity research.

In research on intergroup relations, country images are analyzed with a particular focus on countries' political actions, motivations, and abilities (Herrmann et al., 1997; Oskamp, 1965). The perceived quality of the relationship between countries is often an integral part of the image, e.g., in concepts of the 'enemy country image' (Jervis, 1976) or the 'ally country image' (Cottam, 1977). Further, central elements of the country image are the strengths and weaknesses of a country and its status as an enemy (Boulding, 1956, 1959; Cottam, 1977; Holsti, 1967; Shimko, 1991; Silverstein and Holt, 1989; White, 1965). More recent models, like the stereotype content model (SCM) or the model of behaviors from intergroup affect and stereotypes (BIAS), suggest warmth and competence as two universal dimensions in intergroup perceptions (Cuddy et al., 2007; Fiske et al., 1999, 2007). Generally speaking, research on intergroup relations - in a similar way to marketing research - has a tendency to underemphasize affective and emotional components that may affect how people behave toward another group (Hogg, 2006, p. 487) and is interested mainly in extreme forms of prejudice and intergroup conflict (Brown, 2011; Hogg, 2006). Accordingly, in the majority of the works, especially those on 'enemy image,' but also in the SCM and BIAS models, country images are specified as simplistic stereotypes rather than as differentiated attitudes. Furthermore, due to its perspective, this line of research generally applies a dichotomous distinction between 'in-group' and 'out-group'; hence comparative analyses of specific publics are rare. Lastly, the focus on the human collective excludes nonhuman dimensions like the scenery and landscapes of a country.

The related field of collective identity research analyzes the identity of countries or nations as one distinct form of collective identity (David and Bar-Tal, 2009). Country identity can be described as the image citizens have of their own country or their 'country self-image' (Rusciano, 2003). It can foster the joint awareness among citizens that they share a common identity (Ashmore et al., 2004) and cultivate an understanding of a country as a unique community (Anderson, 1983). While national identity is constructed vis-à-vis a world public that constructs the global reputation of a country (Rusciano et al., 1997), the social group of the nation may employ identity management in an effort to improve its global reputation (Ellemers, 1993). Research on collective identity has so far largely focused on small groups and there is a gap in understanding collective identity on the macro level of countries (Huddy, 2001). Furthermore, David and Bar-Tal (2009) point out 
that the few existing psychological studies on national identity, like Herman (1977) or Bloom (1990), generally focus on the process of individual identification and barely address the generic dimensions of national identity and their specific content.

\section{The political science perspective}

From the perspective of political science, country images are studied regarding matters of international affairs, political identity, and behavior. Concepts of country image, identity, reputation, and brand have been developed and applied mostly in the subfields of international relations and political anthropology.

Within the subfield of international relations country images are studied mostly with regard to the concept of public diplomacy, i.e., the strategic communication of a nation-state aimed at enhancing the country's reputation among foreign publics (see Leonard et al., 2002; Schatz and Levine, 2010; Vickers, 2004). A positive country image and reputation is seen as a means of building common understanding in the international system (Wang, 2006), thereby increasing the political action ability of a nation-state (Vickers, 2004). The central aspect is often seen in the affective image component or a country's 'ability to attract' as it constitutes a nations 'soft power' in the international system (Nye, 2004). So far, research in public diplomacy is strongly influenced by practitioners (c.f. Snow and Taylor, 2009) and by the nation branding literature (Anholt, 2006), with respective concepts and methods still in the developing stages (Gilboa, 2008). One of the most pressing gaps is the conceptual and empirical development of instruments applicable for measurement and evaluation in public diplomacy practice (Banks, 2011; Fitzpatrick, 2007; Pahlavi, 2007), in order to make assessable the desired impact on awareness, attitude, and behavior (Banks, 2011, p. 29). In addition, it is argued that analyses need to include a wider range of target groups like elites, politicians, and journalists (Banks, 2011; Hall, 2010).

The field of political anthropology introduces a differentiated understanding of countries as culturally constructed national entities. Whereas some researchers have adopted a 'radical constructivist' perspective to characterize national entities as mere cultural inventions (e.g., Anderson, 1983; Gellner, 1983; Hobsbawm, 2006), others have developed 'ethnographically grounded' concepts that allow to define some more or less continuous attributes (e.g., Hroch, 1996; Smith, 1991; Wehler, 2011). According to these authors, manifest dimensions of the nation are, for instance, the occupancy of a distinct 'homeland,' common myths, and a shared history and the existence of a single economy (Smith, 1991). So far, these approaches have mainly been used to analyze nations and nationalism as a political ideology. However, recent works in nation branding (Dinnie, 2008) and collective identity research (David and Bar-Tal, 2009) have started to adopt concepts from leading scholars like Anderson (1983), Gellner (1983), or Smith (1987) to study country image and identity by including both cognitive and affective components of the constructs. 


\section{The communication science perspective}

From the perspective of communication science, country images are studied as discursive phenomena in personal, organizational, and mass-mediated communication. The construct has attracted attention in analyses on international communication, on media content and effects, and - to a lesser extent - on organizational communication and communication management.

So far, communication science has mainly focused on mass-mediated country images. Analyses of the dynamics and patterns of the international news flow reveal the (unequal) salience of countries in international news (Chang, 1998; Golan and Wanta, 2003; Jones et al., 2013; Weaver et al., 1984; Wu, 1998), show the strong effect of mass-mediated country images on the formation of public opinion about foreign countries (McNelly and Izcaray, 1986; Manheim and Albritton, 1984; Perry, 1987; Salwen and Matera, 1992; Semetko et al., 1992; Wanta et al., 2004), and underscore the gatekeeping role of foreign editors in forming these mediated country images (Marten, 1989). The central role of mass media in the formation of country images has stimulated numerous content analyses evaluating images of certain countries as portrayed in foreign media (e.g., Sreberny-Mohammadi et al., 1985; Steenhoff, 1996; Wu, 1997). The conceptualization of the country image in these works is predominantly unidimensional (e.g., covering valence from positive to negative tonality) or based on (stereotypical) topics and themes found in media content (e.g., mountains, banking, and chocolate for Switzerland).

In the field of communication management that has a predominant focus on corporate communication, the study of country images has so far received only limited attention (Dyke and Vercic, 2009; Kunczik, 2003). Some researchers have shown a positive effect of public relations activities on country images in U.S. news coverage (Albritton and Manheim, 1983, 1985; Manheim and Albritton, 1984; Zhang and Cameron, 2003) and on public opinion (Kiousis and $\mathrm{Wu}, 2008$ ). Others have addressed the potential and challenges of communication strategies for the cultivation of country images and brands (Kunczik, 1997; Volcic, 2008) as well as country reputation (Wang, 2006, 2008). Only few have addressed questions regarding the conceptualization of the country image construct in detail. Recently, Passow et al. (2005) and Yang et al. (2008) successfully applied a model of corporate reputation in analyses of country reputation. In contrast to the concepts from country-of-origin research, these works not only focus on functional aspects but also stress the importance of social dimensions like the social and ecological responsibility of a country. Despite these latest achievements, there is still much to be done in applying recent advancements from the field of communication management (e.g., Eisenegger and Imhof, 2008; Thiessen and Ingenhoff, 2011) to the conceptualization and specification of country images. These newer works go beyond the corporate focus and draw on more generalizable models including functional, normative, and affective dimensions. This allows for a specification of the concepts regarding a wide range of collective entities and is an advantage especially for more complex and variable entities such as countries. 


\section{Applying the perspective of communication management}

Returning to the argument regarding the need for integrative approaches in the study of country images (Papadopoulos, 2004), the literature review discloses a manifest terminological challenge: There is, of course, no widely accepted conceptual understanding of the country image within any of the individual research fields. Depending on study objectives, country images are understood as brand associations, cognitive and/or affective attitudes, stereotypes, self-perceptions (i.e., identity), mass-mediated information, or social reputation. In doing so, the different fields also tend to employ either a micro-level (mostly business studies and social psychology) or a macro-level (mostly political science and communication science) of analysis. This heterogeneity complicates any transfer across the different approaches and suggests that for integrative efforts a common framework is needed.

Below, we apply the meso-level perspective of communication management to accomplish the following research goals: In order to enhance the commensurability of research on country images we aim to systemize the basic concepts of country image, country reputation, country brand, and country identity, and to clarify their conceptual borders as well as their interrelations. To show how available approaches can be integrated, we subsequently derive a comprehensive "4D Model' of the country image, which can be applied to different countries and utilized for comparative analyses of country images in different groups and contexts.

The perspective of communication management focuses on the meso-level of communication between an organization and its publics. The goal of communication management is often seen as drawing on the organizational identity to build a favorable image among different key stakeholder groups by means of strategic communication, ultimately aiming to safeguard and strengthen the degree of trust in the organization and thereby facilitating favorable stakeholder behavior (see Figure 1). From this analytical perspective, national agencies and the nationstate as a whole - seen as an 'actor of world society' (Meyer and Jepperson, 2000) - appear as the organizational entities. Accordingly, communication management means the management of communication between a nation-state and its (foreign) publics, sometimes also referred to as international public relations (Kunczik, 2003; Zaharna, 2000) or public diplomacy (Leonard et al., 2002; Snow and Taylor, 2009). An analysis of country images from the perspective of communication management thus unfolds three fundamental and interrelated levels of analysis: The identity of a country, the processes of international communication about countries, and the opinions and attitudes toward a country that form in these processes among relevant publics or stakeholder groups.

\section{Systemizing concepts of country image, reputation, brand, and identity}

The terms country image, country reputation, country brand, and country identity constitute important concepts in the different approaches from business studies, 


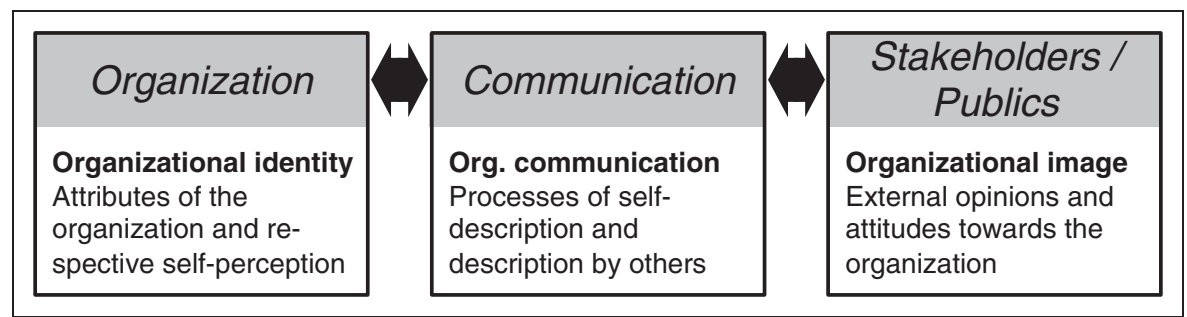

Figure I. Conceptual relations between organizational identity, communication, and image.

social psychology, political science, and communication science and are central to research in communication management. Currently, in each of the fields, there are very different ideas on how to distinguish between these constructs, how to model their interrelations, or even (as is often the case with image and reputation and also brand and image) how to assimilate them.

When aiming to integrate available knowledge across the different fields, it is necessary to develop a basic framework that coordinates these closely related concepts by clarifying lines of conceptual demarcation as well as interrelation. It is important to note, however, that such a framework can merely be a means to interrelate concepts in a way that helps us to integrate knowledge across a range of fields, not provide a set of exclusive and universally applicable definitions - which would not be desirable. We argue that - from the perspective of communication management - all four concepts can be systemized along two basic axes by differentiating between (a) the primal perspective and (b) the constitutive process underlying each of the concepts.

In the meso-perspective of communication management it is common to build on the fundamental distinction between the realm of the organization on the one hand and the organization's environment on the other, the latter of which can be further segmented into an organization's various external publics or stakeholder groups (Freeman, 1984; Grunig and Hunt, 1984). This distinction of perspective (y-axis) can be employed to systemize country image, reputation, brand, and identity by clarifying whether a concept is based within the realm of the nation-state or in the international context of its foreign publics. This bilateral classification can be further refined when clarifying whether the constitutive process of a concept relies primarily on individual perception or on public communication (x-axis). When referring to each of the constructs, these two axes allow for the clarification and coordination of conceptual differences as well as interrelations between country image, reputation, brand, and identity within a single terminological framework (see Figure 2).

Analogous to a widely used image concept, the country image can be defined as 'the sum of beliefs, attitudes, and impressions that a person or group of persons has of an object' (Barich and Kotler, 1991, p. 95); in this case of a country. This concept can be further differentiated when distinguishing between the individual and the collective image, both of which are assimilated in Barich and Kotler's 


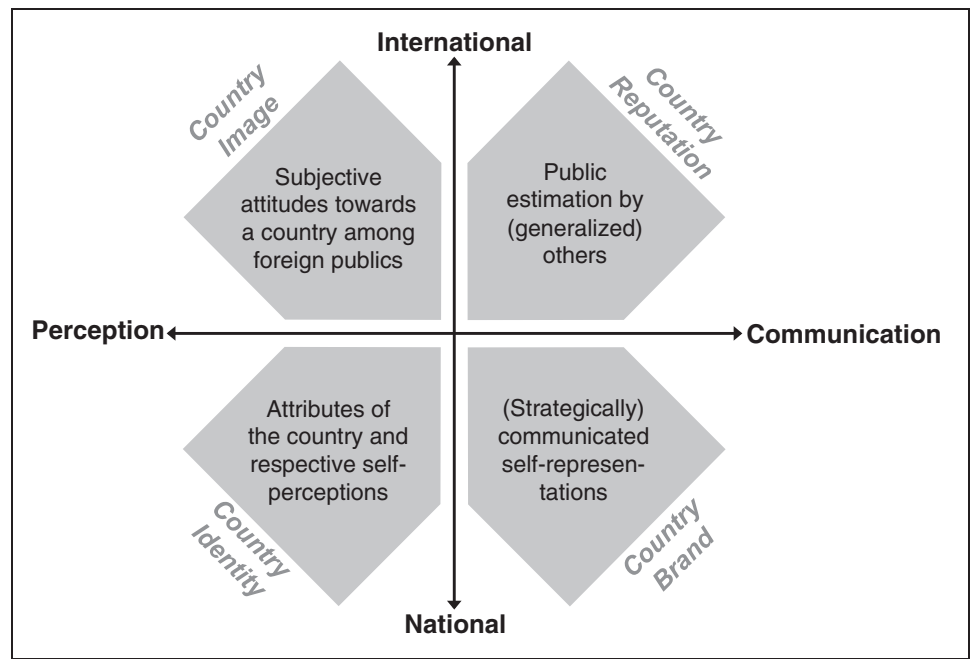

Figure 2. A coordinative framework of country image, reputation, brand, and identity.

definition. To make a clear distinction between a country image as an individual judgment made by a subjective behavior unit (Boulding, 1969) on the one hand, and the accumulated country image of a group on the other, it is useful, when referring to the latter, to speak of aggregated images. The above-mentioned definition should also be further qualified by introducing a differentiation of perspective: It has been stressed that there should be a clear conceptual distinction between outside perception (by foreign publics) and self-perception (of a domestic population) (Grunig, 1993). To account for this differentiation it is useful to distinguish between the concepts of country image and country identity.

While the country image is conceptualized as the perception among foreign publics, country identity refers to the self-perception of a country's citizens (Rusciano et al., 1997). Country identity here means a form of collective identity based on the individual level (Ashmore et al., 2004; Rusciano, 2003). Therefore, when speaking of the country image, we refer to the perception of a country that exists among its foreign publics (out-group), while country identity is conceptualized as the domestic self-perception existing among a country's domestic public (in-group). This analytical distinction should not veil the fact that domestic publics can in fact be very diverse. Respective of study objective it may make sense to further classify here along the lines of, e.g., migrants, regional populations, or ethnic minorities. In their constitution, both constructs, image and identity, are interrelated as country identity is shaped in constant 'negotiation processes' with the publicly communicated images held by foreign publics and vice versa (Rusciano, 2003).

These publicly communicated images, in turn, become important as they accumulate to form the global reputation of a country (Rusciano et al., 1997), which can be conceptualized as an emergent construct. In communication management, 
reputation is commonly defined as the overall estimation of an organization by all its stakeholders (Fombrun, 1996). Correspondingly, it is not an individual's attitude (image), but the public esteem in which a social entity - in this case a country - is held. Here, the aforementioned term of aggregated images can be useful to substantiate the distinct character of reputation: Reputation is more than just an aggregated image; defined as the public esteem, it is based on 'social, not individual judgments' (Emler, 1990, p. 181). Country reputation is therefore not merely the sum, but the emergent synthesis of multiple individual attitudes about a country as the result of complex communication processes in modern media societies (Thiessen and Ingenhoff, 2011). As such, country reputation develops in the international environment of a country when evaluative assessments of that country are publically communicated (mainly via mass media) by generalized others. This publicized 'prestige information' can exercise a considerable degree of social pressure on countries, leading them to conform to 'world opinion' so as not to risk penalties or isolation (Rusciano et al., 1997).

A brand, according to a common definition, is 'a name, term, sign, symbol or design, or a combination of these intended to identify the goods and services of one seller or a group of sellers and to differentiate them from those of competitors' (Kotler and Armstrong, 2013, p. 255). As such, the brand is first of all an intentionally designed strategic self-representation. Although in academic literature there is often a distinction between the brand as communicated by an organization and the brand as conceived by its relevant target groups, the latter aspect can - with reference to the definitions established earlier-be conceptually aligned with the understanding of the image (or in this case "brandimage') and as such lies beyond the primary concept of the brand. In line with this understanding, the country brand is seen as a product of strategically communicated information of a nation-state about itself. It is closely connected to the country identity, which constitutes the necessary basis for any consistent selfrepresentation.

Defined as such, the concepts of country image, country reputation, country brand, and country identity can be systemized by drawing on the distinction, introduced earlier, between the characteristics of primal perspective (national versus international) and constitutive process (perception versus communication). Deployed as basic axes of demarcation, these characteristics help to clarify not only the distinct characteristics of the individual concepts, but also their mutual dependency due to their convergent interrelation within the broader social interaction process in which public communication is individually perceived and individual perceptions become part of public discourse.

\section{A '4D Model' of the country image}

To develop our integrative model of the country image we refer to three basic concepts: The concept of national identity by Smith (1991) to substantiate generic 
attributes of the reference object of the country; the attitude theory by Ajzen and Fishbein (1980) as a foundation for the constitutive components of attitudes which build the cognitive foundation for the image construct; and the model of reputation as a multidimensional construct (Eisenegger and Imhof, 2008; Ingenhoff and Sommer, 2007), which serves as a framework for differentiating between multiple dimensions of the country image. By integrating these concepts, the country image is derived as a subjective stakeholder attitude toward a nation and its state, comprising specific beliefs and general feelings in a functional, a normative, an esthetic, and a sympathetic dimension.

The image object of the country is conceived of as the unity of a nation and its state. By drawing on Smith's (1991) concept of national identity, the country can be defined as a named human collective consisting of six generic attributes: a distinct territory or 'homeland,' a common history and traditions, a domestic economy, a public culture, a set of common norms and values, as well as a sovereign political organization or state (see Figure 3). These attributes lend themselves well as a foundation for the model because they can be conceptually substantiated by Smith's widely used theory on nations, have been successfully applied in research on country identity (David and Bar-Tal, 2009), and correspond to categories by which foreigners actually perceive and distinguish between different countries (Mittelstaedt et al., 2004).

Having defined the image object as such, the country image is conceptualized correspondingly as an attitude toward a country, i.e., the attitude toward a country's territory, its history and traditions, its domestic economy, public culture, norms and values, as well as its political organization. Thereby, it is possible for our model to 'use the same descriptive dimensions to characterize the image and the object' (Kelman, 1965, p. 26). As such, the model is well suited for comparative

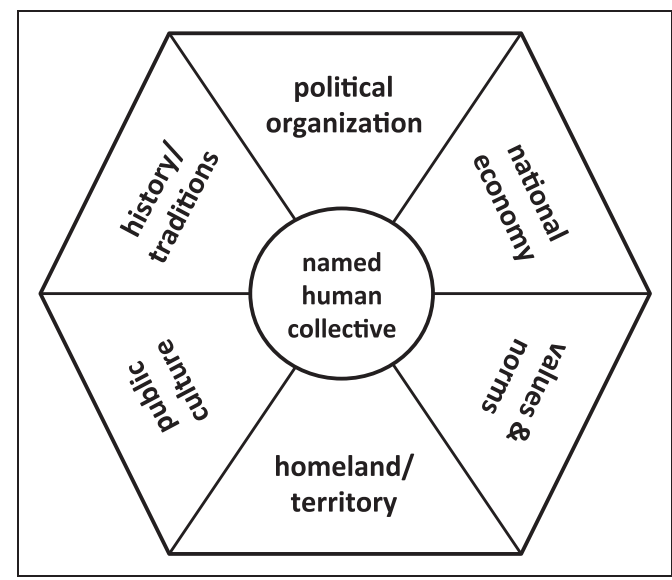

Figure 3. Attributes of a country based on Smith (1991). 
analyses of a country's citizens' self-image, i.e., the country identity, and the image of the country as perceived by foreign publics.

Following the concept of attitudes from the Theory of Reasoned Action (Ajzen and Fishbein, 1980; Fishbein and Ajzen, 1975), country images then comprise a component of beliefs (cognitive component) and a component of emotions (affective component) toward the image object. While the cognitive component can be seen as consisting of multiple specific evaluations regarding a broad range of attributes of the image object, the affective component consists of a necessarily general judgment regarding its sympathy (Bergler, 2008). Hence, the country image comprises (a) what people know (or think they know) about the different attributes of a country and (b) people's general feelings toward the country.

To further differentiate these two general components we draw on a recent model of corporate reputation (Eisenegger and Imhof, 2008; Ingenhoff and Sommer, 2007). According to this model, each social object is judged according to ones beliefs about its functional qualities (abilities, competences, and success), its normative qualities (integrity), as well as its emotional qualities (sympathy and fascination). Ingenhoff and Sommer (2010) also specify the internal structure of the construct by showing that the functional and the normative dimension can be seen as antecedents of sympathy. This is in line with the concept of the Standard Learning Hierarchy from the Theory of Reasoned Action, which assumes a somewhat rational process in which what we know about an object affects how we feel toward this object. Although this hierarchy of effects can vary according to context (Ajzen, 2001), the standard learning hierarchy can be seen as the normal case of the constitution of attitudes (Pelsmacker et al., 2013) and can serve as the basic assumption for the analysis of country images (Bloemer et al., 2009).

Furthermore, to coherently apply this 3D model — which has been developed in the context of companies - to the image object of the country as conceptualized on the basis of Smith's theory we need to integrate an additional dimension:

While functional judgments can refer to country attributes of the national economy and political organization, and normative judgments can be aligned with Smith's country attribute of norms and values, the attributes of public culture, traditions, and landscapes resist coherent affiliation with any of the three dimensions. These attributes relate to esthetic judgments, which, in the model by Eisenegger and Imhof (2008), appear to be associated with the sympathy dimension. But when following Ingenhoff and Sommer (2010) in including a general sympathy dimension as a dependent outcome of beliefs about a country, esthetic evaluations should be conceptualized-like functional and normative ones - as a separate dimension influencing feelings of sympathy toward a country. Otherwise esthetic evaluations (e.g., about the natural beauty of a country's landscapes) would be misconceptualized as outcomes of functional and normative judgments. Thus, to make this model entirely suited for analyzing country images, we further differentiate it by adding a fourth dimension that captures beliefs regarding the esthetic qualities of a country, that is its beauty and attractiveness as a cultural and scenic place. Accordingly, the country image is conceptualized as consisting of four 
different, but closely interrelated, dimensions: a functional, a normative, an esthetic, and a sympathetic dimension. According to the two-component model of attitudes (Ajzen and Fishbein, 1980; Fishbein and Ajzen, 1975), the functional, normative, and esthetic dimensions constitute the cognitive component, while the sympathetic dimension constitutes the affective component of the country image (see Figure 4).

In summary, with respect to the three concepts of national identity, image as attitude, and 3D reputation, we define the country image as a subjective stakeholder attitude toward a nation and its state, comprising specific beliefs and general feelings in a functional, a normative, an esthetic, and a sympathetic dimension.

With this conceptual model, we can consistently specify all cognitive image dimensions by referring to the country attributes as defined on the basis of Smith's (1991) theory. The functional country image dimension, which covers beliefs regarding the competences and competiveness of a country, is specified with reference to the two country attributes of national economy and political organization. This dimension consists of specific judgments regarding the state of the economy and national businesses, the competitiveness of a country's products and services, its labor markets and educational system, the competences and effectiveness of the political system, as well as the country's performance in research and technology. The normative country image dimension, which covers beliefs regarding the integrity of a country, is specified in relation to the country attribute of norms and values. According to a common differentiation, this dimension consists of specific judgments regarding both the social and the ecological responsibility of a country. The esthetic country image dimension, which covers beliefs regarding the esthetic qualities and the attractiveness of a country as a cultural and scenic place, is specified by drawing on the country attributes of public culture, traditions, and territory. It

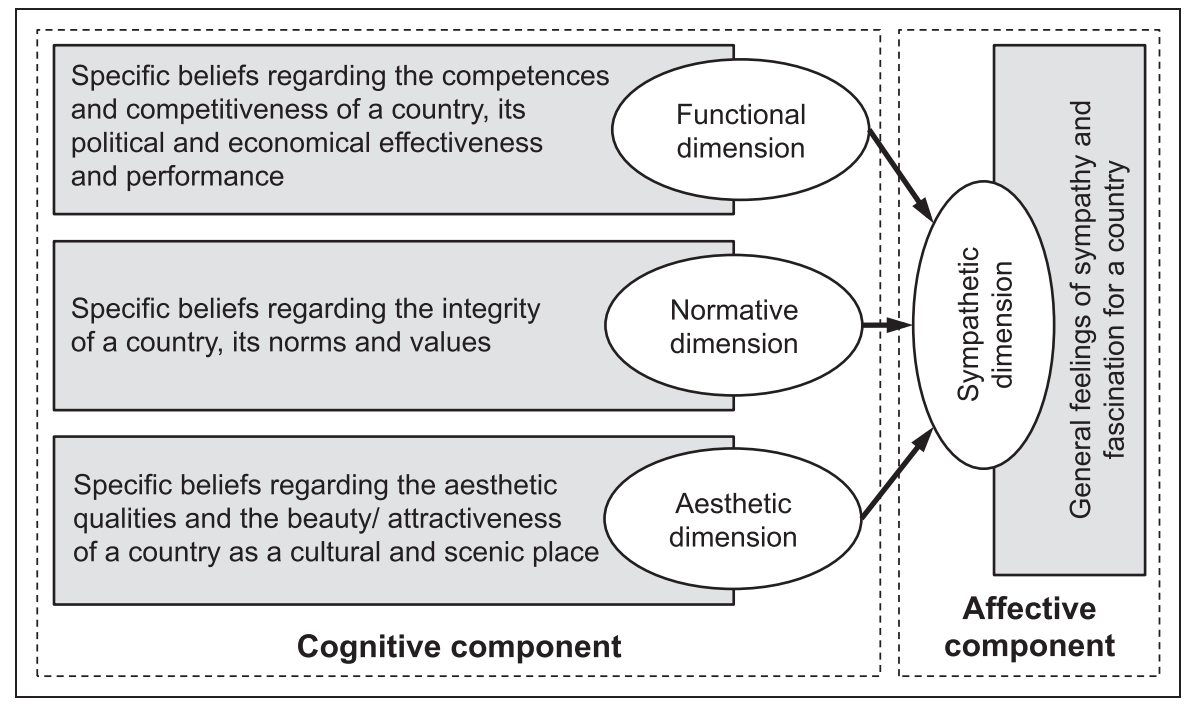

Figure 4. The 4D Model of the country image. 
comprises specific judgments regarding the attractiveness of a country's culture and traditions as well as the beauty of its landscapes. Finally, the sympathetic country image dimension, which constitutes the affective component of the country image construct, consists of general feelings of sympathy and fascination for a country.

\section{Conclusions and discussion}

This article provides a comprehensive and synoptical overview of advances in conceptualizing country images in business studies, social psychology, political science, and communication science and shows how available knowledge from these fields can be consolidated in order to derive an integrative model of the country image. By applying the meso-perspective of communication management, a basic terminological framework is established that helps to interrelate the approaches from the different fields. Subsequently, a new 4D Model of the country image is derived by integrating concepts from national identity research, attitude theory, and reputation management.

By adopting the meso-perspective of communication management, it is possible to systemize the central concepts of country image, country reputation, country brand, and country identity in a coordinative framework using the primal perspectives and the constitutive processes as basic criteria of demarcation. While country image and identity are seen primarily as attitudinal constructs in that they are based on processes of perception, country brand and reputation are seen as constructs of representation which are formed primarily through public communication processes. Furthermore, country image and reputation are established within the sphere of a country's international publics. Thus, located primarily 'outside' the realm of the nation, these constructs are to be distinguished from country identity and brand, which are related to national self-perception and -communication. Besides drawing these lines of demarcation, the established framework also highlights that the four key constructs remain mutually interrelated as public communication is individually perceived and individual perceptions become part of public discourse.

Starting from this terminological framework, concepts of national identity, image as attitude, and 3D reputation can be integrated in order to model the country image as a subjective stakeholder attitude toward a nation and its state, comprising specific beliefs and general feelings in a functional, a normative, an esthetic, and a sympathetic dimension. While functional, normative, and esthetic judgments constitute the cognitive component, the sympathetic dimension constitutes the affective component of the country image. This latter dimension is also seen as the dependent outcome of country cognitions: Beliefs about a country's competences, its values, and norms as well as its attractiveness as a cultural and scenic place affect general feelings of fascination and sympathy for that country.

The approach presented here is the first to develop a coordinative framework that systemizes central concepts in the study of country images from different field perspectives and develops an integrative and multidimensional model of the country image. By suggesting a common terminological framework, this work also 
provides a valuable basis for further integrative studies involving concepts of country image, country reputation, country brand, and country identity.

In empirical applications, the developed 4D Model can be utilized to clarify how strongly different cognitive image dimensions (functional, normative, esthetic) contribute to the formation of the affective component (sympathetic dimension). Better understanding these relations is highly relevant, for instance, in public diplomacy research where the model can help to analyze how the different functional dimensions contribute to a country's 'ability to attract.' Additionally, when placed in the context of public relations research, the model is suitable for analyzing the role of the country image in the formation of trust and legitimation as determinants of a country's potential freedom of action in the international system. Depending on study objective as well as operationalization, this general 4D Model can further be applied to comparative analyses of different country's images in different publics or stakeholder groups. As such, it can help to clarify differences in the constitution of specific country image dimensions among different groups like foreign investors, politicians, political publics, tourists, students, or skilled workers. Similarly, the model can be operationalized to clarify specific discrepancies between country selfperceptions (country identity) on the one hand and the external perceptions (country image) of foreign publics on the other. When combining this 'identity-versusimage' perspective with the focus on specific groups mentioned earlier, migrants, for instance, can pose an interesting object of study as they develop country images and identities orthogonal to the coarse distinction of national/international. When focusing only on the national level, the model is suited to compare the country identity of different subnational groups; besides migrants this can include ethnic minorities or regional groups in distinct cultural/language regions such as in Switzerland, the U.S., or Belgium.

Furthermore, the conceptual link to the Theory of Reasoned Action allows for the specification of the country image as an antecedent of conative variables. Thus, the 4D Model can be applied in analyses of the effects of the country image on behavior. Including variables on intended behavior regarding political support, travel, or investment practices will help to better understand the specific economic, cultural, or political implications of the construct. Combined with the comparative perspective on different groups, such analyses can deliver important insights on relevant differences in how the four country image dimensions influence the behavior of central stakeholders groups such as politicians or investors. Lastly, if the attitudinal component of the model is discarded, the established dimensions of the model can be applied to analyses of self-representations as in studies on country brand management (Kernstock and Brexendorf, 2009) or mass-mediated country reputation in content analyses (Ingenhoff et al., 2013).

\section{Acknowledgements}

The authors thank the anonymous reviewers for their valuable and constructive comments on the article. 


\section{References}

Ajzen I (2001) Nature and operation of attitudes. Annual Review of Psychology 52: 27-58. Ajzen I and Fishbein M (1980) Understanding Attitudes and Predicting Social Behavior. Englewood Cliffs, NJ: Prentice-Hall.

Albritton RB and Manheim JB (1983) News of Rhodesia: The impact of a public relations campaign. Journalism Quarterly 60: 622-628.

Albritton RB and Manheim JB (1985) Public relations efforts for the Third World: Images in the news. Journal of Communication 35: 43-59.

Allred A, Chakraborty G and Miller SJ (1999) Measuring images of developing countries: A scale development study. Journal of Euromarketing 8: 29-49.

Anderson B (1983) Imagined communities: Reflections on the origin and spread of nationalism. London: Verso.

Anholt S (2006) Public diplomacy and place branding: Where's the link? Place Branding 3: 271-275.

Ashmore RD, Deaux K and McLaughlin-Volpe T (2004) An organizing framework for collective identity: Articulation and significance of multidimensionality. Psychological Bulletin 130: 80-114.

Banks R (2011) A Resource Guide to Public Diplomacy Evaluation. Los Angeles: Figueroa Press.

Barich H and Kotler P (1991) A framework for marketing image management. Sloan Management Review 32: 94-104.

Bergler R (2008) Identität und Image. In: Bentele G, Fröhlich R and Szyszka P (eds) Handbuch Der Public Relations. Wissenschaftliche Grundlagen Und Berufliches Handeln. Wiesbaden: VS Verlag fuür Sozialwissenschaften, pp. 321-334.

Bloemer J, Brijs K and Kasper H (2009) The CoO-ELM model: A theoretical framework for the cognitive processes underlying country of origin-effects. European Journal of Marketing 43: 62-89.

Bloom W (1990) Personal Identity, National Identity and International Relations. Cambridge Studies in International Relations. Cambridge: Cambridge University Press.

Boulding KE (1956) The Image. Ann Arbor: University of Michigan Press.

Boulding KE (1959) National images and international systems. The Journal of Conflict Resolution 3: 120-131.

Boulding KE (1969) National images and international systems. In: Rosenau JN (ed.) International Politics and Foreign Policy. New York, NY: Free Press, pp. 422-431.

Brijs K, Bloemer J and Kasper H (2011) Country-image discourse model: Unraveling meaning, structure, and function of country images. Journal of Business Research 64: 1259-1269.

Brown G, Chalip L, Jago L, et al. (2010) Developing brand Australia: Examining the role of events. In: Morgan N, Pritchard A and Pride R (eds) Destination Branding: Creating the Unique Destination Brand. New York: Butterworth-Heinemann, pp. 279-305.

Brown R (2011) Prejudice: Its Social Psychology. Oxford: John Wiley \& Sons.

Chang T-K (1998) All countries not created equal to be news: World system and international communication. Communication Research 25: 528-563.

Child IL and Doob LW (1943) Factors determining national stereotypes. The Journal of Social Psychology 17: 203-219.

Chon K-S (1990) The role of destination image in tourism: A review and discussion. Tourism Review 45: 2-9. 
Cottam RW (1977) Foreign Policy Motivation: A General Theory and a Case Study. Pittsburgh: University of Pittsburgh Press.

Cuddy AJC, Fiske ST and Glick P (2007) The BIAS map: Behaviors from intergroup affect and stereotypes. Journal of Personality and Social Psychology 92: 631-648.

David O and Bar-Tal D (2009) A sociopsychological conception of collective identity: The case of national identity as an example. Personality and Social Psychology Review 13: 354-379.

Desborde RD (1990) Development and testing of a psychometric scale to measure country-oforigin image. Unpublished PhD dissertation, Florida State University, USA.

Dichter E (1962) The world customer. Harvard Business Review 40: 113.

Dinnie K (ed.) (2008) Nation Branding: Concepts, Issues, Practice. London: ButterworthHeinemann.

Eisenegger M and Imhof K (2008) The true, the good and the beautiful: Reputation management in the media society. In: Zerfaß A, van Ruler B and Sriramesh K (eds) Public Relations Research: European and International Perspectives and Innovations. Wiesbaden: VS Verlag für Sozialwissenschaften, pp. 125-146.

Ellemers N (1993) The influence of socio-structural variables on identity management strategies. European Review of Social Psychology 4: 27-57.

Emler N (1990) A social psychology of reputation. European Review of Social Psychology 1: 171-193.

FDFA (2014) Presence Switzerland, Swiss Federal Department of Foreign Affairs. Available at: http://www.eda.admin.ch/eda/en/home/dfa/orgcha/gensec/prs.html (accessed 7 July 2014).

Fishbein M and Ajzen I (1975) Belief, Attitude, Intention and Behavior: An Introduction to Theory and Research. Reading, MA: Addison-Wesley.

Fiske ST, Cuddy AJC and Glick P (2007) Universal dimensions of social cognition: Warmth and competence. Trends in Cognitive Sciences 11: 77-83.

Fiske ST, Xu J, Cuddy AC, et al. (1999) (Dis)respecting versus (dis)liking: Status and interdependence predict ambivalent stereotypes of competence and warmth. Journal of Social Issues 55: 473-489.

Fitzpatrick K (2007) Advancing the new public diplomacy: A public relations perspective. The Hague Journal of Diplomacy 2: 187-211.

Fombrun CJ (1996) Reputation: Realizing Value from the Corporate Image. Boston, MA: Harvard Business School Press.

Freeman RE (1984) Strategic Management: A Stakeholder Approach. Boston: Pitman.

Gellner E (1983) Nations and Nationalism. Oxford: Basil Blackwell.

Gertner D (2011) Unfolding and configuring two decades of research and publications on place marketing and place branding. Place Branding and Public Diplomacy 7: 91-106.

Gertner RK (2010) Similarities and differences of the effect of country images on tourist and study destinations. Journal of Travel and Tourism Marketing 27: 383-395.

Gilboa E (2008) Searching for a theory of public diplomacy. The Annals of the American Academy of Political and Social Science 616: 55-77.

Gilmore F (2002) A country - can it be repositioned? Spain - the success story of country branding. Journal of Brand Management 9: 281-293.

Golan G and Wanta W (2003) International elections on US network news: An examination of factors affecting newsworthiness. International Communication Gazette 65: 25-39. 
Grunig JE (1993) On the effects of marketing, media relations, and public relations: Images, agenda and relationships. In: Ambrecht $\mathrm{W}$, Avenarius $\mathrm{H}$ and Zabel $\mathrm{U}$ (eds) Image Und $P R$. Kann Image Gegenstand Einer PR-Wissenschaft Sein? Opladen: Westdeutscher Verlag, pp. 263-295.

Grunig JE and Hunt T (1984) Managing Public Relations. New York, NY: Holt.

Hall I (2010) The transformation of diplomacy: Mysteries, insurgencies and public relations. International Affairs 86: 247-256.

Han CM and Terpstra V (1988) Country-of-origin effects for uni-national and bi-national products. Journal of International Business Studies 19: 235-255.

Häubl G (1996) A cross-national investigation of the effects of country of origin and brand name on the evaluation of a new car. International Marketing Review 13: 76-97.

Herman SN (1977) Jewish Identity: A Social Psychological Perspective. Beverly Hills: SAGE Publications.

Herrmann RK, Voss JF, Schooler TYE, et al. (1997) Images in international relations: An experimental test of cognitive schemata. International Studies Quarterly 41: 403-433.

Heslop LA, Papadopoulos N, Dowdles M, et al. (2004) Who controls the purse strings: A study of consumers' and retail buyers' reactions in an America's FTA environment. Journal of Business Research 57: 1177-1188.

Hobsbawm EJ (2006) The Invention of Tradition, 14th print. ed. Canto. Cambridge: Cambridge University Press.

Hogg MA (2006) Intergroup relations. In: Delamater J (ed.) Handbook of Social Psychology. New York: Kluwer, pp. 479-501.

Holsti OR (1967) Cognitive dynamics and images of the enemy. In: Finley D, Holsti O and Fagen R (eds) Enemies in Politics. Chicago, IL: Rand-McNally, pp. 25-96.

Hroch M (1996) From national movement to the fully-formed nation: The nation-building process in Europe. In: Balakrishnan G (ed.) Mapping the Nation. New Delhi: Verso, pp. 87-97.

Huddy L (2001) From social to political identity: A critical examination of social identity theory. Political Psychology 22: 127-156.

Ingenhoff D, Lais C and Zosso J (2013) Länderimages und die Rolle der Kultur. In: Ingenhoff D (ed.) Internationale PR-Forschung. Konstanz: UVK, pp. 183-206.

Ingenhoff D and Sommer K (2007) Does ethical behaviour matter? How corporate social responsibility contributes to organizational trustworthiness. Paper presented at the 57th Annual Conference of the International Communication Association (ICA). San Francisco, USA.

Ingenhoff D and Sommer K (2010) Spezifikation von formativen und reflektiven Konstrukten und Pfadmodellierung mittels Partial Least Squares zur Messung von Reputation. In: Woelke J, Maurer M and Jandura O (eds) Forschungsmethoden Für Die Markt- Und Organisationskommunikation. Köln: Herbert von Halem, pp. 246-288.

Jaffe ED and Nebenzahl ID (2001) National Image and Competitive Advantage: The Theory and Practice of Place Branding. Copenhagen: Copenhagen Business School Press.

Jervis R (1976) Perception and Misperception in International Politics. Princeton, NJ: Princeton University Press.

Jones TM, Aelst PV and Vliegenthart R (2013) Foreign nation visibility in U.S. news coverage: A longitudinal analysis (1950-2006). Communication Research 40: 417-436.

Kaneva N (2011) Nation branding: Toward an agenda for critical research. International Journal of Communication 5: 117-141. 
Katz D and Braly K (1933) Racial stereotypes of one hundred college students. Journal of Abnormal and Social Psychology 28: 280-290.

Kelman HC (1965) Socio-psychological approaches to the studies of international relations: Definition of scope. In: Kelman HC (ed.) International Behaviour. A Social-Psychological Analysis. New York: Holt Rinehart and Winston, pp. 3-39.

Kernstock J and Brexendorf TO (2009) Implications of Habermas's "theory of communicative action" for corporate brand management. Corporate Communications: An International Journal 14: 389-403.

Kiousis S and $\mathrm{Wu} X$ (2008) International agenda-building and agenda-setting exploring the influence of public relations counsel on US news media and public perceptions of foreign nations. International Communication Gazette 70: 58-75.

Klingberg F (1941) Studies in measurement of the relations among sovereign states. Psychometrika 6: 335-352.

Kotler P and Armstrong G (2013) Principles of Marketing. Essex: Pearson.

Kotler P and Gertner D (2002) Country as brand, product, and beyond: A place marketing and brand management perspective. Journal of Brand Management 9: 249-261.

Kühn R (1993) Das Made-In Image Deutschlands im internationalen Vergleich. Marketing ZFP 15: 119-128.

Kunczik M (1997) Images of Nations and International Public Relations. Mahwah, NJ: Erlbaum.

Kunczik M (2002) Globalisation: News media, images of nations and the flow of international capital with special reference to the role of rating agencies. Journal of International Communication 8: 39-79.

Kunczik M (2003) Transnational public relations by foreign governments. In: Sriramesh K and Vercic D (eds) Global Public Relations Handbook: Theory, Research \& Practice. New York: Routledge, pp. 399-424.

Kusunoti K (1936) Mental characteristics of the Japanese as seen by Japanese and American students. Japanese Journal of Applied Psychology 4: 232-237.

Leonard M, Stead C and Smewing C (2002) Public Diplomacy. London: Central Books.

Loo T and Davies G (2006) Branding China: The ultimate challenge in reputation management? Corporate Reputation Review 9: 198-210.

McNelly JT and Izcaray F (1986) International news exposure and images of nations. Journalism Quarterly 63: 546-553.

Magnusson P and Westjohn SA (2011) Is there a country-of-origin theory? In: Jain SC and Griffith DA (eds) Handbook of Research in International Marketing. Cheltenham: Edward Elgar, pp. 293-316.

Manheim JB and Albritton RB (1984) Changing national images: International public relations and media agenda setting. The American Political Science Review 78: 641-657.

Marten E (1989) Das Deutschlandbild in der amerikanischen Auslandsberichterstattung: Ein kommunikationswissenschaftlicher Beitrag zur Nationenbildforschung. Wiesbaden: Deutscher Universitäts-Verlag.

Martin IM and Eroglu S (1993) Measuring a multi-dimensional construct: Country image. Journal of Business Research 28: 191-210.

Meyer JW and Jepperson RL (2000) The "actors" of modern society: The cultural construction of social agency. Sociological Theory 18: 100-120. 
Mittelstaedt JD, Hopkins CD, Raymond MA, et al. (2004) Perceived differences among countries: Understanding relative perceptions. Journal of International Consumer Marketing 17: 7-31.

Morgan N, Pritchard A and Pride R (eds) (2010) Destination Branding Creating the Unique Destination Proposition, 2nd rev. ed. New York: Butterworth-Heinemann.

Nebenzahl ID and Jaffe ED (1996) Measuring the joint effect of brand and country image in consumer evaluation of global products. International Marketing Review 13: 5-22.

Newburry W (2012) Waving the flag: The influence of country of origin on corporate reputation. In: Barnett ML and Pollock TG (eds) The Oxford Handbook of Corporate Reputation. Oxford: Oxford University Press, pp. 240-259.

Nye JS Jr (2004) Soft Power: The Means to Success in World Politics, New edition. ed. Cambridge, MA: Public Affairs.

Olins W (2002) Branding the nation - The historical context. Journal of Brand Management 9: 241.

Oskamp S (1965) Attitudes toward U.S. and Russian actions: A double standard. Psychological Reports 16: 43-46.

Pahlavi P (2007) Evaluating public diplomacy programmes. The Hague Journal of Diplomacy 2: 255-281.

Papadopoulos N (2004) Place branding: Evolution, meaning and implications. Place Branding 1: 36-49.

Papadopoulos NG and Heslop L (1993) Product-Country Images: Impact and Role in International Marketing. New York: Routledge.

Passow T, Fehlmann R and Grahlow H (2005) Country reputation. From measurement to management: The case of Liechtenstein. Corporate Reputation Review 7: 309-326.

Pelsmacker PD, Geuens M and van den Bergh J (2013) Marketing Communications: A European Perspective, 5th rev. ed. London: Pearson Education Limited.

Perry DK (1987) The image gap: How international news affects perceptions of nations. Journalism Quarterly 64: 416-421, 433.

Peterson RA and Jolibert AJP (1995) A meta-analysis of country-of-origin effects. Journal of International Business Studies 26: 883-900.

Price R (2003) Transnational civil society and advocacy in world politics. World Politics 55: 579-606.

Puaschunder J, Schweiger G and Kirchler E (2004) Ländervergleich Österreich, Deutschland, Schweiz in Australien. Werbeforschung und Praxis 1: 8-13.

Reindl A and Schweiger G (2006) Stabilität und Kontinuität von Länderimages dargestellt anhand einer Studie aus Indonesien. Werbeforschung und Praxis 2: 28-32.

Roth KP and Diamantopoulos A (2009) Advancing the country image construct. Journal of Business Research 62: 726-740.

Rusciano FL (2003) The construction of national identity - A 23-nation study. Political Research Quarterly 56: 361-366.

Rusciano FL, Fiske-Rusciano R and Wang M (1997) The impact of "world opinion" on national identity. International Journal of Press/Politics 2: 71-92.

Salwen MB and Matera FR (1992) Public salience of foreign nations. Journalism and Mass Communication Quarterly 69: 623-632.

Schatz E and Levine R (2010) Framing, public diplomacy, and anti-Americanism in central Asia. International Studies Quarterly 54: 855-869. 
Schooler RD (1965) Product bias in the central American common market. Journal of Marketing Research 2: 394-397.

Schweiger G (1988) Österreichs Image im Ausland. Wien: Norka Verlag.

Schweiger G (1992) Österreichs Image in Der Welt Ein Weltweiter Vergleich Mit Deutschland Und Der Schweiz. Wien: Service-Fachverlag.

Schweiger G and Kurz H (1997) Herkunftstypische Positionierung und Werbung: Die Nutzung des Image Österreichs und österreichischer Regionen für die Vermarktung österreichischer Produkte. Der Markt - International Journal of Marketing 36: 48-92.

Semetko HA, Brzinski JB, Weaver D, et al. (1992) TV news and U.S. public opinion about foreign countries: The impact of exposure and attention. International Journal of Public Opinion Research 4: 18-36.

Shimko KL (1991) Images and Arms Control. Ann Arbor: University of Michigan Press.

Silverstein B and Holt RR (1989) Research on enemy images: Present status and future prospects. Journal of Social Issues 45: 159-175.

Smith AD (1987) The Ethnic Origins of Nations. Oxford: Blackwell.

Smith AD (1991) National Identity. Reno: University of Nevada Press.

Snow NE and Taylor PM (2009) The Routledge Handbook of Public Diplomacy. New York: Routledge.

Sreberny-Mohammadi A, Nordenstreng K, Stevenson R, et al. (1985) Foreign news in the media: International reporting in 29 countries. Final report of the "Foreign Images" study undertaken for Unesco by the International Association for Mass Communication Research. Paris: Sagi.

Srikatanyoo N and Gnoth J (2002) Country image and international tertiary education. Journal of Brand Management 10: 139-146.

Steenhoff P (1996) Decolonization completed: The role of the Indonesian press in the imagebuilding of The Netherlands between November 1991 and December 1992. International Communication Gazette 55: 1-16.

Sun HH (2008) International political marketing: A case study of United States soft power and public diplomacy. Journal of Public Affairs 8: 165-183.

Tapachi N and Waryszak R (2000) An examination of the role of beneficial image in tourist destination selection. Journal of Travel Research 39: 37-44.

Thiessen A and Ingenhoff D (2011) Safeguarding reputation through strategic, integrated and situational crisis communication management: Development of the integrative model of crisis communication. Corporate Communications: An International Journal 16: 8-26.

van Dyke MA and Vercic D (2009) Public relations, public diplomacy, and strategic communication: An international model of conceptual convergence. In: Sriramesh K and Vercic D (eds) The Global Public Relations Handbook: Theory, Research, and Practice. New York: Routledge, pp. 822-842.

van Ham P (2008) Place branding: The state of the art. Annals of the American Academy of Political and Social Science 616: 126-149.

Verlegh PWJ and Steenkamp J-BEM (1999) A review and meta-analysis of country-of-origin research. Journal of Economic Psychology 20: 521-546.

Vickers R (2004) The new public diplomacy: Britain and Canada compared. The British Journal of Politics and International Relations 6: 182-194.

Volcic Z (2008) Former Yugoslavia on the world wide web commercialization and branding of nation-states. International Communication Gazette 70: 395-413. 
Walmsley DJ and Young M (1998) Evaluative images and tourism: The use of personal constructs to describe the structure of destination images. Journal of Travel Research 36: 65-69.

Wang C-K and Lamb CW (1983) The impact of selected environmental forces upon consumers' willingness to buy foreign products. JAMS 11: 71-84.

Wang J (2006) Managing national reputation and international relations in the global era: Public diplomacy revisited. Public Relations Review 32: 91-96.

Wang $\mathbf{J}$ (2008) The power and limits of branding in national image communication in global society. Journal of International Communication 14: 9-24.

Wanta W, Golan G and Lee C (2004) Agenda setting and international news: Media influence on public perceptions of foreign nations. Journalism and Mass Communication Quarterly 81: 364-377.

Weaver JB, Porter CJ and Evans ME (1984) Patterns in foreign news coverage on U.S. network TV: A 10-year analysis. Journalism Quarterly 61: 356-363.

Wee CH, Lim DTE and Tan YWG (1993) The image of countries as locations for investment. In: Papadopoulos N and Heslop LA (eds) Product-Country Images: Impact and Role in International Marketing. New York, NY: Routledge, pp. 311-338.

Wehler H-U (2011) Nationalismus: Geschichte, Formen, Folgen, 4th end. ed. München: Beck'sche Reihe Wissen. C.H. Beck.

Werron T (2014) On public forms of competition. Cultural Studies $\leftrightarrow$ Critical Methodologies 14: $62-76$.

White RK (1965) Images in the context of international conflict. In: Kelman HC (ed.) International Behaviour. A Social-Psychological Analysis. New York: Holt, Rinehart and Winston, pp. 236-276.

Wu HD (1997) An enduring schema: The image of the Chinese in American prime time television dramas. International Communication Gazette 58: 69-86.

Wu HD (1998) Investigating the determinants of international news flow A meta-analysis. International Communication Gazette 60: 493-512.

Yang S-U, Shin H, Lee J-H, et al. (2008) Country reputation in multidimensions: Predictors, effects, and communication channels. Journal of Public Relations Research 20: 421-440.

Zaharna RS (2000) Intercultural communication and international public relations: Exploring parallels. Communication Quarterly 48: 85-100.

Zhang J and Cameron GT (2003) China's agenda building and image polishing in the US: Assessing an international public relations campaign. Public Relations Review 29: 13-28. 